\title{
Total Quality Management in Service Sector: Case Study of Academic Libraries
}

\author{
Sribatsa Pradhan* \\ Xavier University Bhubaneswar, Odisha, India \\ Corresponding author: sribatsa@ximb.ac.in
}

Received August 30, 2014; Revised August 30, 2014; Accepted October 22, 2014

\begin{abstract}
Quality normally focuses on fulfilling needs, and preferences of customers. Customer-driven quality product and service ensure to satisfy the requirements of customer beyond their expectations. As the organizations improve the quality standard of their product and services the customers' expectations change eventually. Keep this in mind, the fast growing organization anticipates the change and improves its quality product and services continuously. This aspect encourages widespread use of quality management tools, including cost of quality, process integrity, and various measurement techniques for the survival of the organization. Total Quality Management (TQM) acts as one of the powerful management tool which integrate both internal and external customer and able to provide quality services with limited resources. Present paper deals with TQM in academic libraries and aims to focus on how they can provide better quality products and services to stake holders. Since continuous change is occurring in the field of library and information services, academic libraries have to offer learning materials in all format, i.e. print (books and Journals, reports) as well as electronics medium(through digital networked information services). Attempt has been made in this paper to examine how academic libraries can able to provide quality services to their customers with limited resources by adopting quality management tool like TQM.
\end{abstract}

Keywords: total quality management, benchmarking, good governance, service sector

Cite This Article: Sribatsa Pradhan, "Total Quality Management in Service Sector: Case Study of Academic Libraries.” Journal of Business and Management Sciences, vol. 2, no. 3A (2014): 29-32. doi: 10.12691/jbms-2-3A-4.

\section{Introduction}

For survival of an organization quality plays a vital role. The product or services provided by an organization satisfy its customers. While buying a product customers have certain expectation about the product and services. If product and services meets or exceed these expectations from time to time, this will be called as quality products and services. Cost reduction, productivity, team work, communication, problem solving are some of the dynamic skills which are necessary for quality revolution. The process of globalization brought significant changes in the world economy. Service sector is contributing more to the growth of world economy as compared to manufacturing sector. Now a day's service sector accounts for around 50 percent of the GDP of a country. At present service sector in not limited to one nation, it crosses the national boundaries encompassing the entire globe. So service excellence is essential in the global market place. Academic libraries have always committed to provide quality product and service to its users. To provide right information to a right user at right time is the main objective of a library especially academic library, the heart of higher education. This encourages the implementation of TQM approach in academic libraries.

\section{Literature Review}

As per the Juran Institute, Inc. TQM is the set of management process that creates an accountable top management, satisfied customers, empowered employees, high quality product with low cost. This leads to long term sustainability and good economic return. TQM is an effective system for integrating the quality development, quality maintenance and quality improvement efforts of various groups in an organization so as to enable production and service at the most economical level which allows for full customer satisfaction Feigenbaum (1983) [3]. Feigenbaum (1983) [3] advocates that the development, maintenance and improvement of quality in any type of organization depend on satisfied customer. According to Oakland (1993) [12] TQM is an approach to improve the effectiveness and flexibility of business completely. It is an essential way of putting the entire process in order at every level i.e. individual level, department level and the organization level. As advocated by Tobin (1990), TQM is the totally integrated effort for gaining competitive advantage by continuously improving every facet of the organizational culture.

TQM is a total process in which one recognizes that everyone in the organization contributes in some form or the other to achieve the end result i.e. the product. Horwitz (1990) [5]. TQM is not a destination, but a journey towards improvement of the process Hunt (1991). According to Mohanty and Lekhi (2002) [11] TQM is a programmatic long-term systems approach initiated and driven by the top management to bring about a total 
culture change to meet the dynamic needs of the customer and create a loyal and diversified customer base. According to Kanji et al. (1999) [9] TQM is a process of continuously satisfying customer requirements at the lowest possible cost by harnessing the capabilities of everyone.

\section{Elements of TQM}

The elements of TQM is based on the following four major Components like Continuous improvement, Customer Focus, Universal responsibility \& Prevention are shown in the following Figure 1.

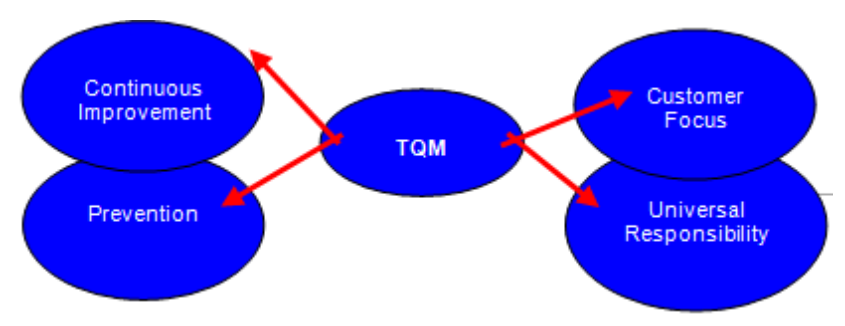

Figure 1. Elements of TQM

Continuous improvement is one of the inherent processes of TQM. It aims at measuring key quality and process areas activities. Once the key areas activities have been noted, the same has been assigned to people to work on it for its continuous improvement through empowerment policy. Continuous improvement aims at finding the shortfalls and its improvements to eliminate undesirable outputs. Everyone has a customer who needs quality products and services. No organization survives without a customer. There are internal as well as external customers in every system. The internal customers who are working in the system can only provide quality products and services to external customers. To produce quality product and services there is a need to develop the internal customers. Universal responsibility is essential in an ideal organization. This philosophy is not only the job of quality assurance department but also job of all the people working in the system. If each one of the system thinks that they have certain responsibility towards their organization then the objective of the organization will be fulfilled. TQM aims to prevent poor quality in products and services, rather than detect and sort out defects. Prevention rather than detection is one of the philosophies of TQM. In order to improve efficiency, the conventional methodology adopted is to find the problem areas and to correct the same.

\section{Academic Libraries: An Over View}

Academic libraries are considered to be the lifeline of academic institutions which support teaching and learning, research and development, generation and dissemination of new knowledge. Libraries in Schools, Colleges, Universities and Research Institutions are the repositories of knowledge. People call this repository of knowledge, the heart of higher education. Conservation and preservation of knowledge, expansion of ideas and dissemination of knowledge are the prime objectives of academic libraries. Faculty, students and staff members are the primary users of an academic library. With the introduction of information technology the nature and scope of library collections and services have changed significantly. Academic libraries no longer restrict themselves to print resources like books, magazines, journals, cataloguing, classification, circulation and reference services. They have extended their collection development policy in the field of Audio Visuals, CDs, eresources, Database and other on-line resources. The academic librarianship is being challenged at every moment and every step due to rapid technological advances. To retain the traditional value of the library as well as to integrate between teaching and learning, the academic librarian needs to make them technology savvy. A study by OCLC in 2012 says that, in United Kingdom 71 percent academic library professionals read journals and 50 percent read blogs to keep them updated with library trends. This is a very good practice for all library professionals. Conservation and preservation of knowledge, dissemination of information, sharing of information to a wider extent, quality information products and services, create atmosphere for self learning for the users community, and participate in the academic activities are the major function of academic libraries.

\section{TQM in Service Sector}

American Marketing Association defines service as activities, benefits or satisfactions, which are offered for sale, or are provided in connection with the sale of goods. "Services are economic activities offered by one party to another: often time-based, performances bring about desired results to receipts, objects, or other assert for which purchaser have responsibility. In exchange for money, time, and effort, service customers expect value from access to goods, labor, professional skills, facilities, networks, and systems; but they do not normally take ownership of any of the physical elements involved Lovelock et al. (1996)”.

Stanton, 1986 says services are those separately identified, and essentially intangible, activities that provide want of satisfaction and that are not necessarily tied to the sale of a product or another service. Kotler (1993) defines services as any kind of performance that one party can offer to another that is essentially intangible and does not results in the ownership of anything. As observed by Mohanty and Lekhi (2002) [11] there are four important characteristics of services i.e., intangibility, perishability, inseparability and heterogeneity. On the whole service sector integrates all the above components, involving a large number of staffs working with a definite purpose to satisfy different needs of the customers.

\section{Principles of TQM for Academic Libraries}

TQM aims at achieving quality in everything one does. TQM is not sudden. It is a changing way towards continuous improvement. Customer focus, Continuous improvement, Prevention verse inspection, people based management, fact based decision making, strong leadership, quality corporate culture, people oriented 
technology, feedback, empowerment, benchmarking, good governance, are the major principles of TQM for academic libraries are as follows:

As discussed the main objective of an academic library is to support the academic communities. Like other service organization academic library delivers product and services to its customers. Here producers and customers meet and interact face to face. The library professionals should understand the user's want and expectations and give more emphasis to satisfy their wants in a systematic way. Priority should be given for user's education by which the users can get his relevant information without wasting time. The collection development policy should be update to the latest curriculum. The service quality needs to be improved from time to time to cope with the technological innovation. Training and development is essential to upgrade the skill and competency of library professionals. Teamwork plays vital role for library collection development policy as well as quality service for the users communities. By the help of flow chart the quality acquisition is possible in a library. Leadership skill of library managers and continuous improvement will definitely improve the service quality of an academic library. Benchmarking is one of the powerful tool for improving the process and service quality in the academic libraries. It helps the library to measure and compare its process and services with similar libraries and also able to find some better process through which they can able to provide world-class services to the users. There are three types of benchmarking process like, internal, competitive and best practice benchmarking. Planning, analysis, integration, action \& maturity are the five major process of benchmarking. The service quality of a library can definitely improved by the help of benchmarking process and practices. It is not enough to provide good services in a library. It needs to be improved continuously. Employee must be involved and empowered in a TQM process. Every employee is recognized as a unique human being and should involve in helping the organization to achieve its goal. Employees and management should join their hands to face the TQM obstacles to achieve organizational goal. Empowered employee is a new concept. Empowered employees are in self-control. They have the means to measure the quality of their own work processes, to interpret the measurement and compare the measurement to goal and take action when the process required and so on. Successful TQM is possible when the entire manpower is engaged and produces product and services in low cost. Lower cost and higher return is possible by effective utilization of manpower. When number of people gathered together with common vision and dedication, with mutual understanding and help among themselves and work interdependently to complete an assignment is called it team work. Each employee of the library should understand the importance of mutual cooperation in this age of globalization which will a part of TQM philosophy. By proper training and development people learn advantage of team work. Training is the basic tool of application of TQM process in modern libraries. Several concepts and techniques are essential for TQM. It is important to improve employees understand the process. The employees must also learn to apply problem the solving techniques. Library should locate all its customers and identify what do they want? Assess their capabilities that what they can provide? What they can do to full fill the customers' expectation o? Like other service industries libraries practice of TQM provide quality product and services with low cost to the user/ customer. Academic libraries now should manage their services to meet increasing demand from variety of users. Thus TQM helps the libraries to change organizational culture, have proper planning, integrate isolated individuals and department, improve organizational structure, have continuous training and education, have effective measurement techniques, good customer care, and continues improvement of service quality. Every top management should take interest to implement TQM as it will bring greater returns. But wholehearted commitment of the top management is essential for effective TQM. This commitment has to be reflected in the governance process and should be explicit to everyone in the organization. Everyone should feel that the top management is dedicated to the organization. They are accountable and transparent in their action. So TQM is not possible without the support of top management.

\section{Conclusion}

Libraries act as the integral parts of higher education aims at quality service. The reputation of a library can be enhanced by improving quality products and services for its users. The indicators, principles, of TQM helps the library professionals as well as library managers to compare their service with similar types of libraries and helps them to adopt best as well as world-class services to their users. Factors such as customers need, designing new services, good housekeeping, feedback, courteous staff, best automation facilities etc. will definitely improve the service quality of a library. The quality of an academic library can be judged by the number of satisfied members. Sufficient infrastructure facilities, good use of books, journals and other e-resources helps the libraries to achieve its goal and able to provide the quality information at users doorstep.

\section{References}

[1] Berk / Berk, (1993) Total Quality Management, Excel Books, New Delhi.

[2] Charantimath, P.M. (2003) Total Quality management, New Delhi, Pearson Education.

[3] Feigenbaum, A.V. (1983). Total Quality Control, 3rd edn., McGraw-Hill, New York.

[4] Harith, M.B. (2013). Total quality Management Indicators in Academic Libraries: In India, JBM \& SSR, New Delhi. 12-16.

[5] Horwitz, C. (1990). Total quality management: an approach for education. Educational Management and Administration, 18 (2): 55-58.

[6] Juran, G. (2000) Juran's Quality Handbook, McGraw-Hill, New York.

[7] Juran, J.M., Godfrey, A B, Hoogstoel, R.E. and Schilling, E.G. (1999). The Quality Improvement Process, Juran's Quality Handbook. 5th edition, McGraw-Hill, New York.

[8] Kanji, G.K. and Tambi, A.M. (1998). Total Quality management and higher education in Malaysia. Total Quality Management, 9 (4/5): 130-132.

[9] Kanji, G.K., Tambi A.M. and Bin, A. (1999). Total Quality Management in UK higher education institutions. Total Quality Management, 10 (1): 129-153.

[10] Khanna, V.K. (2009). TQM: Planning, Design \& Implementation, New Age International (P) Ltd, New Delhi. 
[11] Mohanty, R.P. and Lekhi, R.R. (2002). TQM in the Service Sector, Jaico Publishing House, Mumbai.

[12] Oakland, J.S. (1993). Total Quality Management. Second edition. Butterworth- Heinemann, Oxford.

[13] Oakland, J.S. (2003). TQM: Text with Cases. ButterworthHeinemann.
[14] Pradhan, S. (2009). Benchmarking in Academic Libraries, Bhubaneswar, $10^{\text {th }}$ National MANLINET Proceedings, 287-291.

[15] Pradhan, S. (2011). Total Quality Management in Academic libraries, VSRD Technical and Non- Technical Journal, 3 (10): 376-379.

[16] Wang, H. (2006). From "User" to "Customer": TQM in Academic Libraries. Library Management, 27 (9): 606-620. 